\title{
Article \\ Sustainable Rural Electrification Project Management: An Analysis of Three Case Studies
}

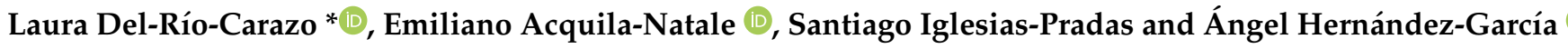

Citation: Del-Río-Carazo, L.; Acquila-Natale, E.; Iglesias-Pradas, S.; Hernández-García, Á. Sustainable Rural Electrification Project Management: An Analysis of Three Case Studies. Energies 2022, 15, 1203. https://doi.org/10.3390/en15031203

Academic Editors: Bernard Ziębicki and Edyta Bielińska-Dusza

Received: 30 December 2021

Accepted: 3 February 2022

Published: 7 February 2022

Publisher's Note: MDPI stays neutral with regard to jurisdictional claims in published maps and institutional affiliations.

Copyright: (C) 2022 by the authors. Licensee MDPI, Basel, Switzerland. This article is an open access article distributed under the terms and conditions of the Creative Commons Attribution (CC BY) license (https:// creativecommons.org/licenses/by/ $4.0 /)$.
Departamento de Ingeniería de Organización, Administración de Empresas y Estadística, ETSI de Telecomunicación, Universidad Politécnica de Madrid, Av. Complutense 30, 28040 Madrid, Spain; emiliano.acquila@upm.es (E.A.-N.); s.iglesias@upm.es (S.I.-P.); angel.hernandez@upm.es (Á.H.-G.) * Correspondence: laura.delrio@upm.es

\begin{abstract}
Universal access to energy is a global challenge for sustainable development that requires granting last-mile access to energy services to rural and isolated communities. However, achieving access is not sufficient: it must be done affordably, reliably and with an adequate quality. Universal access to energy goes beyond the mere selection of a technical solution or infrastructure; it demands being able to design management models for projects aiming to guarantee that households may access energy services in a sustainable way. This study analyzes the main elements (i.e., governance, technological and business models) of management models in universal access to energy projects and their impact on the different dimensions of sustainability (i.e., social, environmental, and economic). The study then presents three case studies of rural electrification projects having different configurations of the management model, with special focus on the differences in the business model, and it analyzes their outcomes from a sustainability perspective. The analysis of the three case studies suggests that the choice of the business model is key to ensuring sustainability, with fee-for-service models giving the best results. The analysis also highlights the importance of collaboration and involvement of the communities in projects engaging multiple agents with different roles.
\end{abstract}

Keywords: management model; rural electrification; sustainability; governance; technology; business model

\section{Introduction}

Universal access to energy is essential to foster and guarantee the progress of lessfavored and isolated rural communities [1]. Energy poverty has become a world problem and a threat to the environment, public health, safety, and the world economy [2]. According to the United Nations, the 17 Sustainable Development Goals (SDGs) cannot be achieved without sustainable energy, which is why high priority was given to affordable and nonpolluting energy in SDG 7 [3].

The world population with access to energy has increased from 83 percent in 2010 to 90.2 percent in 2021. However, and despite the overall improvement in access to energy in the last years, rural areas in developing countries still show access levels that are far from the objectives declared in the 2030 Agenda [4]. In these cases, the main challenge still remains to address the "last mile" problem; that is, to reach to the most vulnerable and isolated communities: 759 million people do not have access to energy yet, of which most of them live in rural areas, representing a total of 85 percent of the global deficit in access to energy services [5].

The SDG 7 states that universal access to energy must be achieved by using renewable energies, improving the efficiency of energy systems, increasing international collaboration, extending the infrastructure and developing technologies [3]. Therefore, guaranteeing access to energy and energy services is not enough: it is imperative to provide reliable and affordable energy of sufficient quality [6]. Additionally, it is necessary to increase the production and delivery of energy services in a way that is compatible with the SDGs, a 
reason why the design of such provision must be made under the principles of universality, diversity and sustainability $[3,7]$.

The origin of the "last mile" challenge is that it makes it very expensive, often prohibitive and not affordable, to provide remote rural communities with energy because the demand for energy from these communities is relatively low. Therefore, energy providers (ESCOs) discard those investments due to the impossibility to make them profitable without increasing their tariffs or having them subsidized by the state; instead, they focus on urban areas, densely populated and with higher average income population [8]. However, for universal access to energy to happen, it is necessary not only to provide access to energy, but also that the energy services are accessible: even when households may access a network or purchase individual energy generation systems, access rates may remain low due to the high initial costs, interconnection fees, wiring, and electric appliances. Hence, universal access to energy requires the development of business models that make access affordable, be it by means of subsidies or payment methods that are compatible with the economy of the households. Long-term sustainability of universal access to energy must also consider the local context and the different agents involved; for this reason, the underlying business models must be tailored to the characteristics of the population and be flexible enough to be consistent with local needs. Therefore, there is no single business model in universal access to energy, but rather different possibilities and characteristics that may be particular to each project. The big challenge is then being able to provide tailored solutions that do not slow down the projects aiming to achieve universal access to energy [5].

Because of the abovementioned barriers, project managers not only need to focus on using high-quality technology that may address local needs but must also ensure that the project's business model is consistent with cultural values, awareness, and the agents involved in the planning and execution of the project [9]. In other words, a correct management of the project will ensure its sustainability through the provision of a reliable, high-quality and affordable access to energy in rural areas [10].

To further clarify what constitutes a correct management in sustainable rural electrification projects, the main objective of this study is the elaboration of a comprehensive management model to analyze how different configurations of the model may affect sustainability. This is one of the main contributions of this study, as existing literature on rural electrification rarely adopts a managerial view of the projects. The analysis involves the examination of three different studies of real projects of rural electrification led by private entities. The remainder of the study is structured as follows. Section 2 lays out the possible configurations of the management model, with three different components (i.e., governance model, technological model, and business model), after observation of previous academic research on rural electrification projects. Furthermore, it links the impact of the different components of the management model with the three pillars of sustainability (social, environmental, and economic). Section 3 analyzes in further detail three study cases of rural electrification carried out by a private entity. Section 4 summarizes and discusses the main findings of the research. Finally, Section 5 presents the conclusions and limitations of the study.

\section{Conceptual Framework}

\subsection{Management Modeling of Rural Electrification Projects}

The configuration of a management model for rural electrification projects is complex and multifaceted. Real cases of rural electrification projects cover primarily the technological elements, project funding and the roles of the different agents involved [11], even though the terminology varies from one case to another [12]. From a wider perspective, the configuration of the management model requires the consideration of aspects relative to ownership, operation and maintenance, selection of technologies, viability and feasibility, funding, or stakeholders' roles, among others [11-14]. This study synthetizes these elements in three fundamental components: governance model, technological model, and business model (Figure 1). While governance may often be equated to the broader 
idea of project management, in rural electrification projects its scope extends to ownership of the initiative or project, the operation of energy provision and the relationships between actors/stakeholders [13,14]. A similar clarification is required in the case of the business model; while some may limit this component to the funding of the project, the business model covers more aspects, such as system acquisition, maintenance, or payment methods [12].

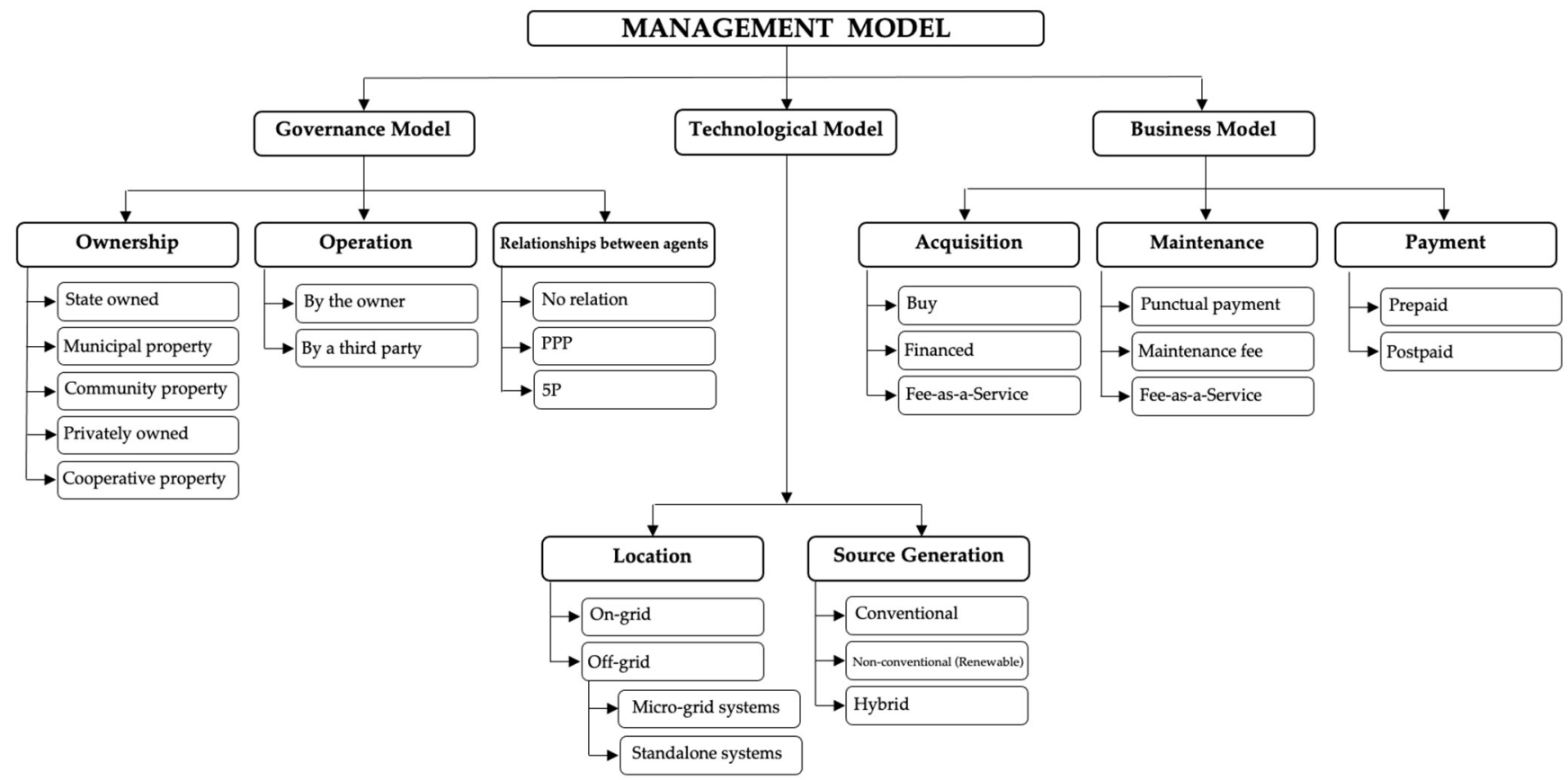

Figure 1. Management model for rural electrification projects.

\subsubsection{Governance Model}

Based on classifications of governance models of rural electrification projects found in prior research, we can highlight three main elements: ownership of the project, operation of the service and the relationships between agents $[13,15,16]$. Regarding ownership, the projects may be state owned, privately owned, municipal property, community property, and cooperative property [15]. State ownership refers to projects planned by the state and generally managed by existing electric companies [17]; in contrast, privately owned projects are those in which the systems and/or network that grant access to energy belong to the end users or a private company [18-20]. Ownership falls in municipality or local authority, or in the community, when the energy systems or network have been donated by an entity (public or private) but the control and management of the electric service has been transferred to the local authorities or to the community, respectively [21]. A final option is that of cooperative ownership of the project, in which a group of individuals oversees, implements and collectively owns the energy provision service to satisfy their energy access needs [22].

Regardless of ownership, the owner of the project is not necessarily responsible for the operation and maintenance of the service; from the perspective of operation and economic management of the service, there are two different options: either the service is operated by the owner or by a third party $[13,23]$. When projects are privately owned and operated by the owner, owners are responsible for the operation of the service, even though they may delegate preventive maintenance to end users and corrective maintenance to expert staff [24]; in state-owned projects, operation and preventive and corrective maintenance are generally subcontracted to electric companies; in the case of municipal or community ownership, citizens generally oversee operation and maintenance; finally, when service operation is overseen by a third party, the responsibility for operation and maintenance of the service is transferred to an entity that works autonomously from the owner; the staff of 
the third party has (or receives) the training and qualification to perform preventive and corrective maintenance, and the entity receives economic payments from periodic (weekly, monthly, yearly) service fees $[25,26]$.

The third element of the governance model involves the relationships between the agents participating in the project. Because of the need to mobilize resources to broaden the coverage of the energy service, there are several actors involved in the energy service provision in rural electrification projects in remote areas [11]. From the review of prior experiences, three different forms of participation may be found: non-existent (the owner of the project executes it autonomously and independently), public-private partnerships (PPPs), and pro-poor public-private partnerships (5P) [27]. A PPP consists of agreements between the public and private sector, where resources from both are combined to provide the service; in a PPP, the public sector lays out the regulatory framework and protects the end users rights, while the private participants contribute to the project with resources, knowledge and effective operation. The rise of initiatives oriented to improve universal access to basic services in developing countries has led to the emergence of a new type of relationship (5P), where not only states and private companies collaborate, but also incorporate other agents to the project, such as microfinancing institutions, banks or credit unions, universities and nonprofit, not-for-profit, and non-government organizations (NGOs) [17,21,27]. The main objective of $5 \mathrm{P}$ is the provision of services to poor communities, often ignored in PPP due to business risks. In 5P, poor people are not only users but also project partners; private companies may develop corporate social responsibility initiatives, public bodies may fulfill their obligation to provide universal access to basic services, and the communities may collaborate in broadening such access.

\subsubsection{Technological Model}

Rural electrification projects may rely on different technologies, depending on how dispersed are the potential users or their proximity to an existing electric network [28]. When the citizens and the communities live in areas that are close to an existing grid, and the orography is not a problem, on-grid systems (i.e., extending the existing network) comes up as an optimal solution [29]. On-grid systems provide enough electric power to connect several lighting devices, such as lamps, and other electric appliances [30]. In these cases, existing electric companies take on the initial infrastructure investment and operate the service, including the maintenance of the different systems [31]. When expanding the grid is not possible due to the fact of long distances between the users and the existing network, off-grid solutions are necessary; off-grid systems are independent systems, able to self-generate and store energy [32,33]. Among off-grid systems, there are different options depending on the dispersion of users. If the dispersion is low, microgrids generate energy at a local level and supply electricity to a reduced number of users, who are interconnected through a shared distributed system [19,34,35]; when the dispersion is high, standalone systems (e.g., solar home-systems) are the best solution, especially considering that the cost of grid connection increases with distance from grid [18,36-38].

Energy generation technologies vary depending on the chosen system. Based on the source of energy, they can be categorized as conventional, non-conventional (renewable), and hybrid. Conventional technologies use fossil fuel [38,39], whereas non-conventional technologies refer to those that use exclusively renewable energy sources $[17,21,38,40,41]$ and hybrid technologies combine both $[20,28,38,42]$. As the availability of renewable sources of energy may be variable, non-conventional technologies make it necessary to use energy storage systems, such as batteries; hybrid systems generally try to avoid the use of batteries by incorporating diesel generators and reducing the capacity of storage systems [43]. 


\subsubsection{Business Model}

Ensuring that the business model of service provision is successful entails the collaboration of different agents (e.g., the state, donors, NGOs, or private companies) [44], and different alternatives can be offered to beneficiaries [45]. For instance, ownership of the energy generation system may fall on the end user (customer) or in the owner of the project (if state or privatelyowned). When customers own the system, they may have made a payup-front purchase or have their purchase financed in different payment installments using microcredits [46]. They are also responsible for the maintenance of the system, bearing the costs associated with maintenance and repairs; to avoid exceptional high expenses, another option is to make periodic payments (a maintenance fee), regardless of whether the systems needs repairing or not [45].

If the customer does not own the system, an energy-as-a-service (EaaS) model may be used. EaaS involves that the customer makes a periodic payment for energy provision that includes maintenance and substitution of the system when it reaches end-of-life or end-ofservice-life [18,47]. EaaS improves the affordability of energy access because the energy provider maintains ownership of the system and has a duty to keep it operational [45]. Additionally, in EaaS there are two possible payment methods: prepaid and postpaid [48]; the former allows customers to pay only for the energy used, avoiding expenses when they do not have the money to make the payment (they would not have access to energy in the meanwhile), whereas the latter allows consumers to have access to energy even when they cannot make the payment occasionally (settling the debt in later installments) [49].

Finally, financing of all payments related to access to energy in rural electrification projects generally are subsidized either by the state or other public entities, or by private companies that bear a fraction of the cost of the equipment or the periodic fees; the subsidy may be equal for all customers or proportional to their income.

\subsection{Rural Electrification Management Models and Sustainability}

Achieving sustainability in rural electrification projects is one of the main challenges for developing countries [50,51]. The use of technologies that are tailored to rural areas widens access to energy [7], but selecting the right technology might not be enough, as it is necessary to consider all aspects related to sustainability throughout all the phases of the project, both at a technical and management level [52,53]. For example, choosing the right business model, achieving effective knowledge and technology transfer and including the beneficiaries in the decision making process facilitate the sustainability of the project $[18,54,55]$.

Sustainable development refers to meeting "the needs and aspirations of the present generation without destroying the resources needed for future generations to meet their needs" [55]. A common view of sustainability is that of the three pillars, which differentiates between social, environmental, and economic sustainability [56]. Social sustainability refers to the ability of social identities, relationships, and values to continue in the future [57], which requires that social cohesion is sustained and that individual needs are met [58]. Environmental sustainability represents the ability to improve human well-being, while protecting the sources of raw materials and guaranteeing the integrity of ecosystems [59]. Economic sustainability refers to the ability of a project to sustain a given level of economic production indefinitely $[60,61]$. To better guide the decisions of rural electrification projects, the following subsections analyze the effect of the different possible configurations of the management model presented in Section 2.1 in each of the pillars of sustainability, by taking different frameworks defined to assess sustainability, either with a project management approach $[62,63]$ or a rural electrification view [64-67]. 


\subsubsection{Social Sustainability}

The social dimension focuses on the improvement in the quality of life of the population, and it is associated with the fulfilment of their basic needs and their active participation in society. It is essential that the beneficiaries are involved in the development of the project, from its design to its implementation, so that the projects are adapted to the particular characteristics of the area and it is easier for the communities to appropriate the technology, thus ensuring their awareness and actual use of the solution $[54,68]$.

From the management model, all three components (i.e., governance, technology, and business models) have a direct effect on different aspects related to social sustainability found in prior literature: funding, energy equity, availability of services, availability of support, profile of operation staff, degree of local participation, project duration, and default rate, or affordability.

Funding helps assess whether the beneficiaries can take care of the periodic expenses associated with access to energy, whether they should own the systems or whether the cost of the service is subsidized to facilitate affordable access to the least favored [68]. These decisions are affected by the governance model, through leadership and relationships between actors, and by the business model, when establishing the modality of acquisition.

Energy equity refers to the requirement that the project must focus on poorest communities and with higher barriers in access to energy, regardless of their social condition or the dispersion of such communities [63], which is highly related to the governance model, depending on the involvement of the community in decision making, and to the technology model, in system selection.

The service also must meet a minimum level of service offer and reliability, in what constitutes the availability of services. Such level varies depending on the characteristics of the community and must be analyzed as part of the project planning, considering the specific needs of each potential user. Availability of services may be assessed based on duration of energy shortages or blackouts as well as users' perceptions $[64,69,70]$, and it is highly associated with the technological model. Additionally, beneficiaries may be provided with the necessary resources to repair the systems or replace them if they are beyond repair; in other words, they need to have available support, which must be both accessible and affordable to users [20,69]. Availability of support is therefore associated with the governance model, by defining who is responsible for service operation, and the business model, by the defined maintenance fees.

Regarding the profile of operating staff, the project must include personnel that has the required skills to operate and maintain the project, so that effective knowledge and technology transfer to the beneficiaries is possible [64]. Additionally, the project should include and empower women in such operation and maintenance tasks [68]. These aspects are affected by the governance model, depending on how community participation is incorporated into the project, which also affects the number of local population involved in the design and operation of the project $[62,69]$.

Choices in ownership (i.e., governance model) and service modeling (i.e., business model) have an effect on the duration of the project. Rural electrification projects require an adoption and adaptation period among end users, as well as additional maturing time that facilitates analysis and fine tuning, which is why short and fast implementation projects with no subsequent monitoring should be avoided [68].

Finally, it must be possible to assess whether access to energy is really affordable for the beneficiaries or, on the contrary, it is necessary to revise the business model to change system acquisition or service provision to prevent abandonment by the users, measured as default rate $[20,68,69]$. 


\subsubsection{Environmental Sustainability}

Environmental sustainability considers the different aspects that impact natural resources and local ecosystems of the areas where the project will be implemented [6]. Decisions in the technology component of the management model are the ones with the most direct effect on environmental sustainability, which may be assessed through $\mathrm{CO}_{2}$ emissions, impact on the ecosystem, replacement of other polluting sources or compatibility with future grid services.

$\mathrm{CO}_{2}$ emissions facilitate quantitative comparison and selection of the most appropriate technology to achieve lower levels of pollution. It is necessary that the project management considers which is the right choice among the possible energy sources and systems [61]. Ecosystem impact is based on a qualitative and quantitative analysis of how respectful with the environment is the service infrastructure of the project, both at visual and acoustic levels. At the initiation phase of the project, the decision of the technology must consider and analyze the characteristics of the area and the population, as well as the dispersion of the community $[62,64]$. When developing rural electrification projects, current use of energy sources must be considered, so that the system to be introduced provides the highest reduction in the use of conventional sources and maximizes the use of non-polluting natural resources in the area [68]. Finally, the solution must guarantee the compatibility of the service with future developments and avoid the generation of technological waste due to obsolescence or abandonment of the system [68]; that is, the technology should be flexible and adaptable.

\subsubsection{Economic Sustainability}

The top priority of the project in the economic sustainability dimension of a rural electrification project should be to have the ability to autonomously bear the costs associated with the provision of the service in the future. Achieving economic sustainability requires that the costs of the electric service are high enough to maintain the systems operational in the long term but also low enough to guarantee affordability. Decisions of the business model directly affect economic sustainability and, in general, different business models are piloted, helping fine-tune the model until an optimal balance is achieved [5]. As seen in Section 2.1.3, decisions in the business model include system ownership and acquisition, maintenance mode, and payment methods. In developing countries, system acquisition is often prohibitive to the residents in rural areas. Therefore, ensuring economic sustainability involves the adoption of non-conventional business models where the end users only assume a percentage of the total cost.

Broadly, economic sustainability may be assessed by observing the profitability of the project, operation and maintenance costs, and capital and installation costs [68]. That is, the project must (1) be profitable enough to facilitate scaling up, which is why the business model must consider all the associated costs when fees and prices are set-up; (2) observe the economic resources necessary to ensure continuance of the project (higher economic resources entail higher fees and costs for beneficiaries); (3) consider the initial investment to deploy the technical system for energy provision (higher investment in more difficult implementations).

Table 1 shows a summary of the potential impact of decisions in the configuration of the business model on the three pillars of sustainability. The following section analyzes the effect of different decisions in the configuration of the management model in the sustainability of three real projects of rural electrification. 
Table 1. Impact of decisions in the management model on sustainability in rural electrification projects.

\begin{tabular}{|c|c|c|c|c|}
\hline \multirow[b]{2}{*}{ Dimension } & & \multicolumn{3}{|c|}{ Model Component } \\
\hline & & $\begin{array}{c}\text { Governance } \\
\text { Model }\end{array}$ & $\begin{array}{c}\text { Technological } \\
\text { Model }\end{array}$ & $\begin{array}{c}\text { Business } \\
\text { Model }\end{array}$ \\
\hline \multirow{4}{*}{ Environmental } & $\mathrm{CO}_{2}$ emissions & & $x$ & \\
\hline & Impact on the ecosystem & & $x$ & \\
\hline & Replacement of other polluting sources & & $x$ & \\
\hline & Compatibility with future grid service & & $X$ & \\
\hline \multirow{9}{*}{ Social } & Funding & $x$ & & $x$ \\
\hline & Subsidies & $x$ & & $x$ \\
\hline & Energy equity & $x$ & $x$ & $x$ \\
\hline & Availability & & $X$ & \\
\hline & Maintenance availability & $X$ & & $\mathrm{X}$ \\
\hline & Profile of operators & $x$ & & \\
\hline & Project duration & $x$ & & $x$ \\
\hline & Degree of local ownership & $X$ & & \\
\hline & Default rate & & & $x$ \\
\hline \multirow{3}{*}{ Economic } & Profitability & & & $x$ \\
\hline & Operating and maintenance costs & $x$ & & $x$ \\
\hline & Capital and installation costs & & $x$ & \\
\hline
\end{tabular}

\section{Case Studies}

\subsection{Overview and Previous Considerations}

This section showcases the analysis of three rural electrification projects in remote areas of Peru and Mexico. The three projects were led and developed by acciona.org, the corporate foundation of ACCIONA. Acciona.org's projects are based on four fundamental principles: (1) the projects are aligned with the main activity of the corporation with impact on human development (energy, water, and sanitation), which helps take advantage of the knowledge, expertise, and developed networks on these areas in developing regions while also empowering local employees; (2) prioritization of projects in areas that are less attended by other institutions, primarily impoverished rural and remote areas, where service provision is not planned; (3) the main objective of the projects must be the design of solutions that are sustainable in the long term. To do so, affiliate non-for-profit organizations are established; the affiliate organizations act as service providers, which facilitate the creation of long-term relationships with the beneficiaries; (4) collaboration with other local, national, and international organizations, including public, private and academic institutions, as well as other civil society organizations and local communities.

The three projects share some characteristics in their configuration of the management model. The governance model is based on private ownership of the projects, initiated by acciona.org and executed by their national affiliates, in this case acciona.org Perú and acciona.org México. The relationship model is 5P, with different collaborating actors at all levels. An advantage of the 5P configuration is that it guarantees the support of larger public and private entities to promote the project while bringing closer the potential beneficiaries by means of existing communication channels that facilitate adaptation of the project (e.g., local population, banks and credit unions, NGOs) as well as innovation through collaboration with academic and research institutions. 5P models also help overcome a big limitation of purely private ownership with no relations, where the design and the decisions in the other elements of the management model are mostly driven by the risk 
and low profitability of this kind of projects, which hinders the involvement of the local communities, the understanding of their needs and adaptation of the projects [48,71].

Except for slight differences, the three case studies include similar configurations of their management models in the governance (privately owned, 5P) and technology components (non-conventional, off-grid standalone systems; the technology of the three projects is based on solar home systems due to the dispersion of the communities and long distances to the electric network). Thus, even though the main implications of this configuration on the sustainability of the project will be analyzed, the main focus of the analysis will be the impact of the decisions related to the configuration of the business model on the sustainability of the projects. The following subsections introduce the setting of the three projects and analyze their management model according to the components presented in Section 2.

\subsection{Case Study 1: Luz en Casa Cajamarca}

Peru had a poverty rate of 30.1 percent in 2020. Access to electricity now extends to 98.35 percent of the country, but this figure drops to 92.45 percent in rural areas [71]. The department of Cajamarca, with 1.5 million inhabitants, has the lowest electrification rate in the country due to the wide dispersion of households in rural communities, which account for 70 percent of the population [72]. The "Luz en Casa Cajamarca" project (Table 2) was developed by the Spanish acciona.org foundation and the Peruvian civil association acciona.org Peru - the affiliate of the acciona.org foundation in Peru. The main objective of the project was to improve access to energy in the region of Cajamarca.

Table 2. "Luz en Casa Cajamarca": Project overview.

\begin{tabular}{cc}
\hline Project Title & Luz en Casa Cajamarca \\
\hline Beneficiaries & Residents in Cajamarca, Peru \\
Project Period & 2009-2021 \\
Institutions & acciona.org foundation \\
& acciona.org Peru \\
& Banco Interamericano para el Desarrollo (BID) \\
\hline
\end{tabular}

\subsubsection{Governance Model}

"Luz en Casa Cajamarca" is a privately owned project led by acciona.org. In this project, members of the community are selected to work for acciona.org as freelance technical staff, and they oversee installation, set-up, and corrective maintenance of the systems, and provide support in shortage and reconnection tasks.

Local management of the project is performed by acciona.org, which assumes the project's operational tasks. Acciona.org is supported by a network of volunteers who provide occasional collaboration and by the Committees of Photovoltaic Electrification (CEFs). CEFs are a key agent in the operation of the project, acting as intermediaries between acciona.org and end users, helping in system inspection tasks and preventive maintenance, and collecting, transporting, and depositing the periodic fees associated with the service.

The relationship model can be labeled as $5 \mathrm{P}$, including the collaboration of the acciona.org Foundation as promoter, funding body, coordinator, and supervisor; acciona.org as promoter and long-term operating agent; Ministerio de Energía y Minas (MEM) and Organismo Supervisor de la Inversión en Energía y Minería (OSINERGMIN) as regulators; Banco Interamericano para el Desarrollo (BID) as co-financer; Universidad Politécnica de Madrid (UPM) as academic and technical advisor; municipalities as partners and communities; CEFs as users and representatives.

\subsubsection{Technological Model}

Electricity was generated by second-generation solar home systems (SHS), standalone portable equipment that use renewable energies and allow to reach homes that fall out 
of the grid extension plans. SHS are solar photovoltaic generators rated between 11 and $100 \mathrm{Wp}$ (Watt-peak) and have a storage battery [73]. Second-generation SHS are equipment specifically designed to optimize solar energy use, with higher capacity and efficiency than first-generation systems but lower required power. A novelty of these systems is that they feature a DC-DC voltage adapter for radio to allow radio connection of different voltages below DC $12 \mathrm{~V}$ and a socket to charge mobile phones [74]. Therefore, the service provided by the SHS in the project allows up to four hours of light using spotlights and the charge and use of entertainment and communication equipment, such as mobile devices.

\subsubsection{Business Model}

The business model was based on EaaS, where a monthly fee is charged for service provision. In this model, the users did not buy the systems: the systems were owned by acciona.org, which also oversaw maintenance and replacement in case of system failure or end-of-service-life. The decision to implement EaaS was made upon a cost analysis that showed that it was the only option that could support sustainable operation and maintenance costs, even assuming that the complete initial investment would not be recovered. To ensure affordable tariffs, it was necessary to negotiate with the Peruvian government to design a policy and regulatory framework for regulated tariffs in rural electrification with off-grid photovoltaic systems, and to incorporate the tariff into the national cross-subsidy system. The system established that 80 percent of the fee was paid by the state, and end users payed the remaining 20 percent of the fee. These amounts were set after consideration of the average household expenditure of 16.4 soles in access to energy (kerosene, candles, batteries) prior to the start of the project and the calculation of operation costs of the project to ensure sustainability. Prior to the coming into effect of the framework, the service fee was 15 soles per month, whereas after the implementation of the project, the fee was reduced to 10 soles per month, which was paid periodically once the service was provided (i.e., a postpaid system). Figure 2 shows a summary of the management model of the "Luz en Casa Cajamarca" project.

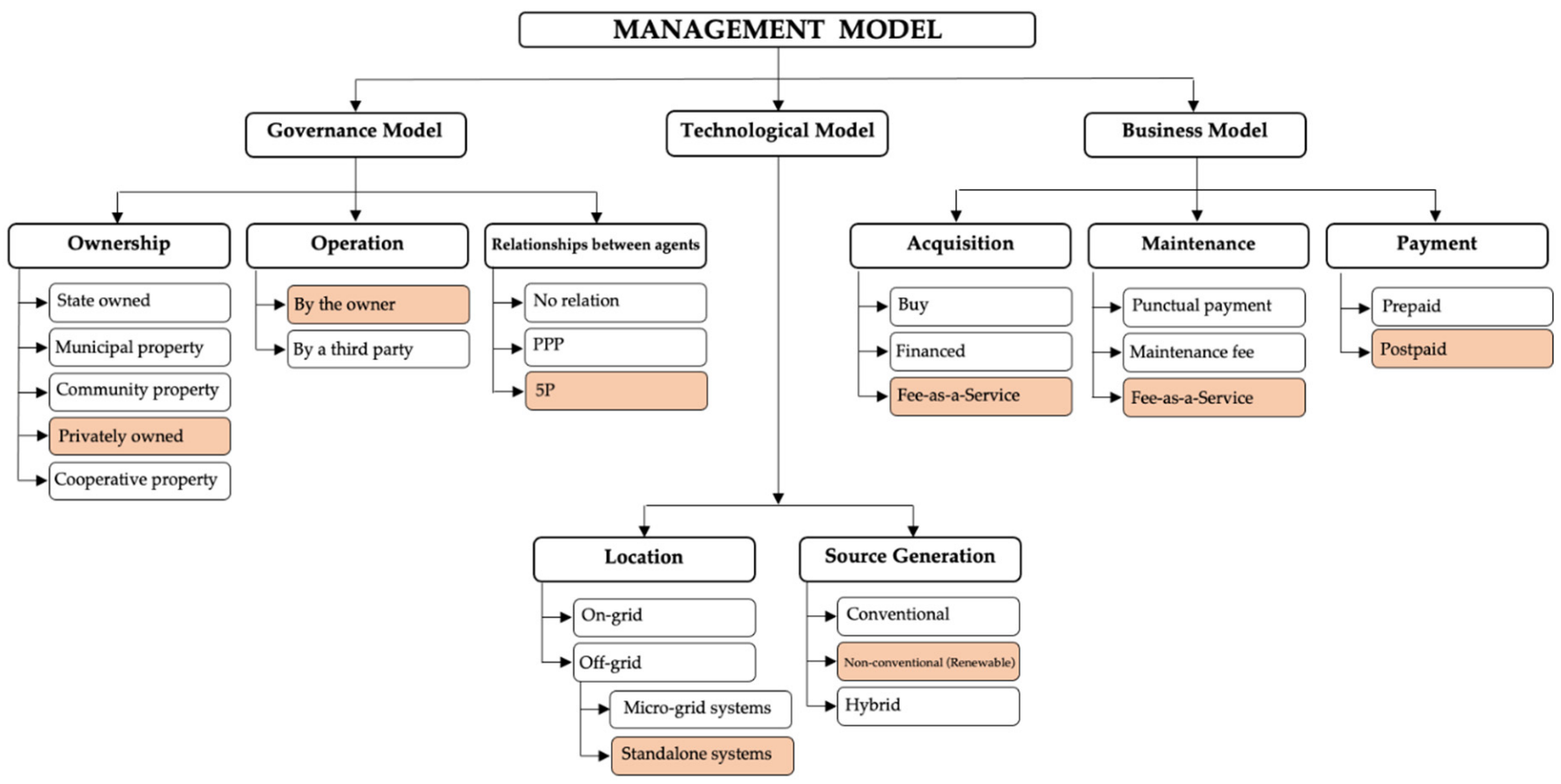

Figure 2. Configuration of the management model of the "Luz en Casa Cajamarca" project. 


\subsubsection{Main Results and Impact on Sustainability}

"Luz en Casa Cajamarca" provides energy to 3910 households spread through 188 different communities after 12 years. With the project, acciona.org set in motion a social model that is close to the community and the users, who are not only beneficiaries of the service but can also take part in the operation and management of the project. The data from quantitative questionnaire-based satisfaction surveys of all users showed high rates of acceptance of the project among beneficiaries; additionally, the model ensured affordable access to energy, as default rates dropped from $3.03 \%$ to $0.19 \%$. Awareness and sensitivity activities in the communities have increased credibility and seem to validate the management model. Users highlight time availability as one of the main advantages of the system, as they now have study and cooking time at night.

The project contributed to prevent the emission of 1544 tons of $\mathrm{CO}_{2}$ per year and the generation of 1.65 tons of battery waste, with a minimal environmental impact due to the use of SHS that do not require the deployment of any additional infrastructure. Energy savings for households was estimated to be 656,880 soles per year (approximately EUR 163,000 per year).

The project made energy fees affordable for users with a balance between revenue and costs that ensures the economic viability and continuity of the project. The technology also helped reduce initial costs associated with infrastructure deployment: standalone SHS cost 2000 soles, compared to a cost of 70,000 soles for grid extension in these areas.

From a sustainability perspective, we observed two main shortcomings of the project. The first of them was related to corrective maintenance and operation, both at economic and human levels; because of the isolated and remote location of households, it is very difficult to supply repair parts, as well as to effectively repair faulty systems and collect service fees. The second shortcoming had to do with the low availability of qualified technical staff; even though the project put emphasis on the identification of users with communication and social mobilization skills to increase awareness and reach all potential beneficiaries, it is still necessary to identify residents with the minimum required technical skills.

\subsection{Case Study 2: Luz en Casa Oaxaca}

In 2010, 3 million people (2.6 percent of the population) did not have access to energy in Mexico yet. In Oaxaca, this percentage rose to 5.3 percent due to the remote and isolated location of the households [75]. The "Luz en Casa Oaxaca" program (Table 3) was ideated by the acciona.org foundation and the local acciona.org México, analogously to "Luz en Casa Cajamarca". The main objective of the project was to improve access to energy in the state of Oaxaca. The project is now included in the broader EncASa Oaxaca program, which seeks to provide integral and universal access to different basic services: electricity, drinking water, sanitation, and clean cooking.

Table 3. "Luz en Casa Oaxaca": Project overview.

\begin{tabular}{cc}
\hline Project Title & Luz en Casa Oaxaca \\
\hline Beneficiaries & Residents in Oaxaca, México \\
Project Period & $2012-2021$ \\
Institutions & acciona.org foundation \\
& acciona.org Mexico \\
& Gobierno del Estado de Oaxaca \\
Agencia Española de Cooperación Internacional para el \\
Desarrollo (AECID) \\
Agencia Mexicana de Cooperación International para el \\
Desarrollo (AMEXCID)
\end{tabular}




\subsubsection{Governance Model}

Same as "Luz en Casa Cajamarca", this project was privately owned by the acciona.org Foundation and acciona.org Mexico. Acciona.org Mexico is formed by a team of local technical staff from the country, which facilitates the communication with the communities (indigenous habitants represent 35 percent of the population in Oaxaca and the region is the most linguistic diverse in the country, with more than seven languages and dialects spoken, such as Mixteco, Zapoteco, and Chinanteco). Acciona.org México is in charge of local management and operation of the project.

The relationship model was $5 \mathrm{P}$, with the collaboration of the acciona.org foundation as promoter, funding body, coordinator and supervisor; acciona.org México as promoter and responsible of the project in the long term; Gobierno del Estado de Oaxaca, Agencia Española de Cooperación Internacional para el Desarrollo (AECID), and Agencia Mexicana de Cooperación International para el Desarrollo (AMEXCID) as co-financers and intermediaries. The international organization KIVA participated as micro-financers, local municipalities acted as partners, and the communities and CEFs participated as end users and representatives.

\subsubsection{Technological Model}

The project consisted of the deployment of third-generation SHS, or pico photovoltaic systems. An additional benefit of third-generation systems when compared to secondgeneration SHS (such as those used in "Luz en Casa Cajamarca") is that they are more compact, lighter, easier to install and use (plug and play), and that they have integrated LED lights that allow for more efficient use of energy, in turn extending the duration of the batteries [74]. Third-generation SHS also use lithium batteries (instead of lead batteries), further reducing the weight of the system which, in turn, facilitates transportation to the communities [76].

\subsubsection{Business Model}

In "Luz en Casa Oaxaca", the end users acquired and owned the systems due to the impossibility of implementing EaaS models when the project started due to regulatory constraints. In this user-ownership model, end users paid for half of the cost of the system and the other half was subsidized by the project's funding bodies. Additionally, if a user could not afford the payment up front, different installments could be made by participating in a micro-credit program directed by KIVA (this program was only active in 2014). As end users owned the systems, they were responsible for maintenance, which entails additional costs beyond the warranty period of the systems.

The model requires higher availability of maintenance than EaaS because the end users have to be able to reach acciona.org's technical staff for diagnostic and repairing tasks. This decision also has an impact on the governance model, by delegating operational tasks in each area to local entrepreneurs who, from the so-called Centros Luz en Casa (CLCs), provide support and receive fee payments; they also establish franchises to sell appliances that are compatible with the SHS in order to extend the functionalities of the systems beyond lighting. CLCs are usually already existing local businesses located in reference sites that dedicate part of their space and time to support "Luz en Casa Oaxaca" users. Local entrepreneurs receive training to provide effective corrective maintenance and keep constant communication with the project's management bodies for fee and stock management; in return, they receive a commission fee for each repaired system or sold item. Currently, the project has five CLCs and four Centros EncASa (the latter offer support for sanitation, cooking and drinking water services, in addition to SHS systems and compatible appliances).

Figure 3 summarizes the management model of the "Luz en Casa Oaxaca" project. 


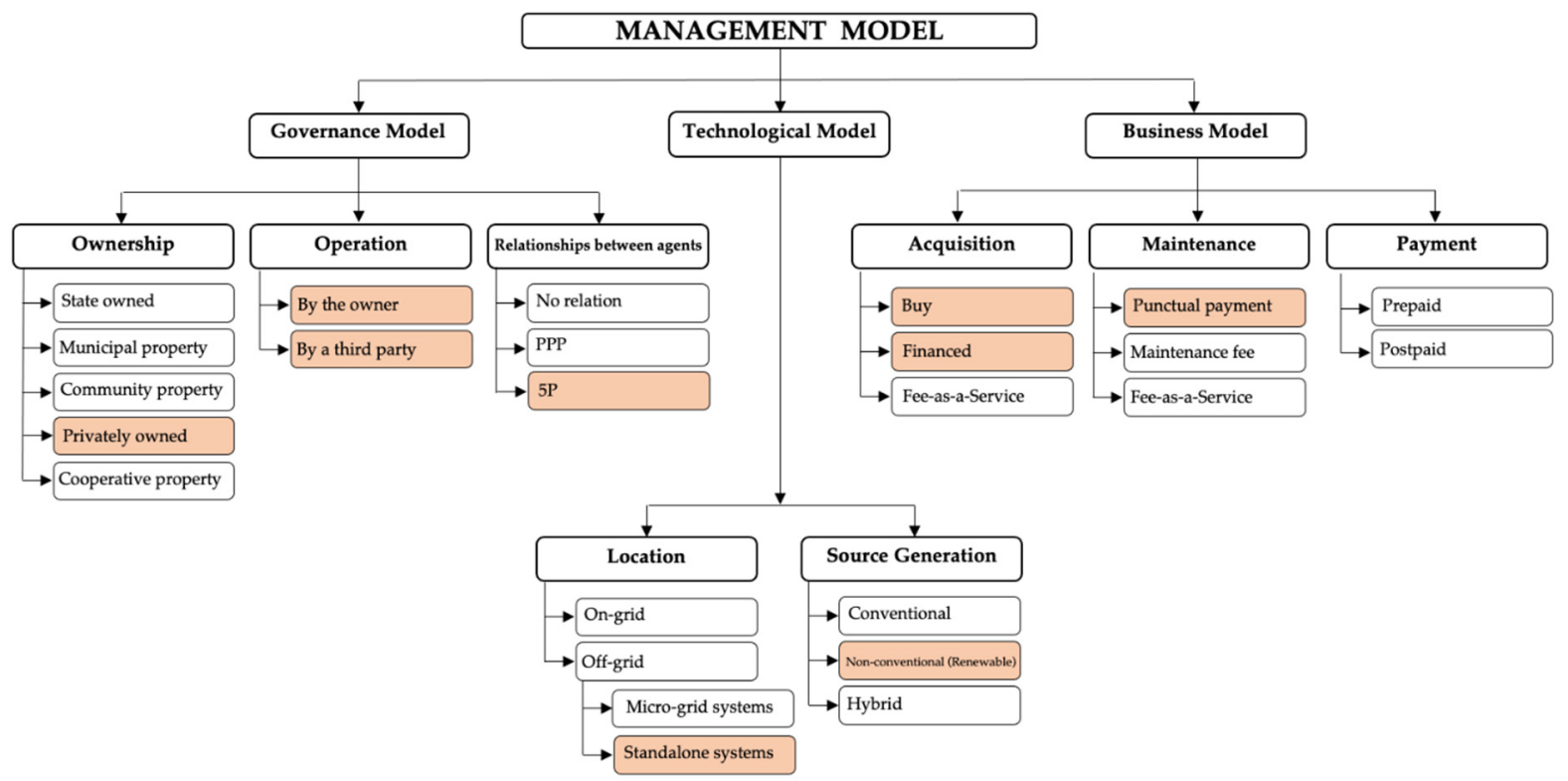

Figure 3. Configuration of the management model of the "Luz en Casa Oaxaca" project.

\subsubsection{Main Results and Impact on Sustainability}

The project, including Luz en Casa Oaxaca and EncASa Oaxaca, provided energy access to 8525 households in 628 communities after 9 years. Acciona.org subsidized the systems through a partnership involving several public and private entities, ensuring affordability for the most needed and improving universal access. The multi-agent configuration, supported by the CEFs and CLCs, provided higher availability of repairing staff than the "Luz en Casa Cajamarca" project through the identification and training of personnel with technical skills, in addition to awareness and social sensibilization skills. Three out of the nine local entrepreneurs were women who have become referents in the communities they provide support to, advancing towards gender equality. The partnership with public agents helped not only subsidize the systems but also improve and facilitate communication with the communities and a previous identification of the communities that would benefit from the project.

The SHS helped prevent the emission of 1075 tons of $\mathrm{CO}_{2}$ per year and 12.42 tons of uncontrolled battery waste, with low impact on the environment. Household energy savings were estimated at $18.75 \mathrm{M}$ pesos per year (approximately EUR 758,200 per year).

The subsidization program reduced cost acquisition in half, facilitating affordability, and the SHS reduced initial and deployment costs.

We observed two elements that could be improved from a sustainability perspective. First, maintenance costs may be high for end users. Because of the business model, costs associated with maintenance and repairing are not included in the price and, therefore, must be bore by the users, increasing costs in the case of system failure. Consequently, repair rates were low and, in some cases, the systems were abandoned when they stopped working because users could not afford the cost associated with repairing or replacing the system. Second, subsidization of system acquisition makes it necessary to increase awareness and sensibilization, as having the system subsidized increases the perception of higher costs if replacements are needed, which in turn may increase system abandonment rates. However, the alternative is to use conventional sources of energy, which are more harmful for both end users and the environment.

\subsection{Case Study 3: Luz en Casa Amazonía (Napo)}

In the Amazon rainforest area, only 82.7 percent of the population has access to electric energy [71], which means that about one in five people do not have access to energy. The "Luz en Casa Amazonía" Project (Table 4), designed by the acciona.org foundation and 
acciona.org Perú, aimed to improve access to electric energy of indigenous communities in the Peruvian Amazon rainforest.

Table 4. "Luz en Casa Amazonía": Project overview.

\begin{tabular}{cc}
\hline Project Title & Luz en Casa Amazonía \\
\hline Beneficiaries & Residents in the Peruvian Napo, Ucayali and Amazonas River basins \\
Project Period & $2016-2021$ \\
Institutions & acciona.org Foundation \\
acciona.org Peru & Agencia Española de Cooperación Internacional para el \\
Desarrollo (AECID) \\
Fondo Nacional de Desarrollo Científico, Tecnológico y de Innovación \\
Tecnológica (FONDECYT)
\end{tabular}

\subsubsection{Governance Model}

Analogously to the previous two projects, "Luz en Casa Amazonía” was privately owned by the acciona.org foundation and acciona.org Peru. Acciona.org Peru is supported by CEFs and has CLCs for local management and operational tasks, including fee collection and payment, repairs, and sales.

The relationships are $5 \mathrm{P}$, with the collaboration of the acciona.org foundation as promoter, funding body, coordinator, and supervisor; acciona.org Peru as promoter and long-term operator; Ministerio de Energía y Minas (MEM) and Organismo Superior de la Inversión en Energía Minera (OSINERGMIN) as regulators and policymakers; the Peruvian Government, Agencia Española de Cooperación Internacional para el Desarrollo (AECID), and Fondo Nacional de Desarrollo Científico, Tecnológico y de Innovación Tecnológica (FONDECYT) as co-financers; Universidad Politécnica de Madrid (UPM), Fundación de Ingenieros del ICAI para el Desarrollo (FICAID), and the Instituto de Investigación Tecnológica (IIT) as academic and technical advisors and partners; municipalities as partners; communities, CLCs (four), and CEFs as users, representatives, and micro-franchises.

\subsubsection{Technological Model}

The technology applied for service provision was based on third-generation SHS (same as in "Luz en Casa Oaxaca"), but using the pay-as-you-go (PAYG) functionality of the system to simplify the payment process. According to the World Bank, PAYG is one of the most effective solutions to provide decentralized access to energy in remote communities of developing countries [77]. PAYG systems, which were not used in the previous two projects, allow for a prepaid system of energy provision in which the end user pays a fee for a code that unblocks the SHS for a period of time. Once that period expires, the user must complete another payment and a new unblocking code is generated, or else the SHS will be blocked. Therefore, PAYG systems facilitate remote management of off-grid systems, reducing default rates and the risk associated with the initial investment [78].

\subsubsection{Business Model}

As in the "Luz en Casa Cajamarca", the energy was provided as EaaS. The business model improves the affordability of the technology: users can also benefit from cross subsidies and the tariff is regulated; therefore, end users only pay 20 percent of the total costs (approximately 9 soles per month). The main difference with the "Luz en Casa Cajamarca" project was that PAYG systems give more freedom to end users, which can accommodate their consumption to their disposable income.

Figure 4 summarizes the management model of the "Luz en Casa Amazonía" project. 


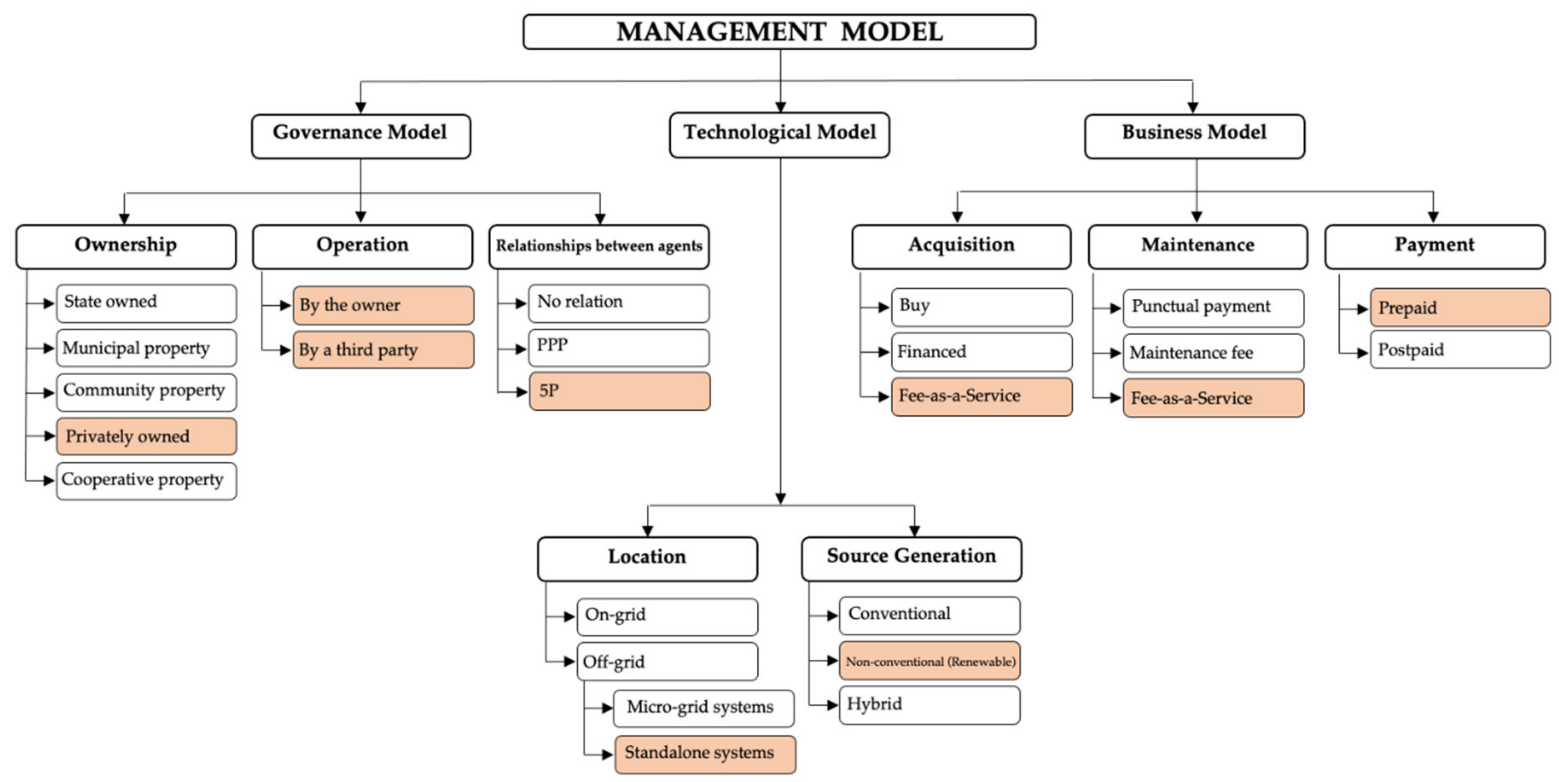

Figure 4. Configuration of the management model of the "Luz en Casa Amazonía" project.

\subsubsection{Main Results and Impact on Sustainability}

The project provided access to energy to 1518 households in 58 communities after 5 years. From a social sustainability perspective, acciona.org spread out a clean electrification solution for remote rural indigenous communities that minimizes the use of fossil fuel. According to satisfaction surveys collected by the project promoter with replies to a quantitative questionnaire of all participants in the pilot project, all the beneficiaries (100 percent) reported the highest level of satisfaction with the use of the SHS, and the majority of them (98 percent) were also satisfied with their energy savings. The multi-agent model and the incorporation of the CEFs and CLCs make service management and operation viable, as the households are only accessible by the river, and the weather conditions (temperature and rain) are extreme, which further complicates distribution and support.

The implementation of PAYG systems also has a positive impact in operation and management because prepaid installments help reduce default rates (which are close to zero) and delays in fee payments (a reduction of 83 percent, from 68 to 11 days). CLCs have made 80 percent of system repairs (including a 13.2 percent rise in the last year), thus reducing trip cost and time of local entrepreneurs and facilitating maintenance.

With a minimal environmental impact, the project has helped reduce 158 tons of $\mathrm{CO}_{2}$ emissions per year and prevented 13 tons of uncontrolled battery waste. The estimated energy savings for all households was 216,133 soles per year (approximately EUR 53,365 per year). The EaaS model also favors environmental sustainability because acciona.org was responsible for the management of faulty systems, which were collected and sent to the provider of the SHS for adequate recycling of each component.

Fees have been made affordable, and the balance between revenue and costs ensures the continuity and economic sustainability of the project.

Despite the good results of the project, we observed a missed opportunity, because EaaS with prepaid modes may enable the use of information and communication technologies to improve fee collection and management, as well as the delivery of activation codes to users.

\section{Discussion}

Upon the analysis of the three case studies of rural electrification project, we can assess the impact of different configurations of the management model in the sustainability of the projects. 


\subsection{Social Sustainability}

First, we observed a strong influence of the governance model in the social sustainability of the project, with better results in the projects where the number of agents involved in the operation of the project was higher. From the three projects under analysis, it is recommended to incorporate actors that (a) facilitate awareness and social sensibilization, (b) facilitate knowledge and technology transfer, and (c) know the local culture and customs [11,71]. For example, the incorporation of the CLCs in the latter two projects was so successful that CLCs have been added to the "Luz en Casa Cajamarca" project, which now has 12 active CLCs. The inclusion of entrepreneur profiles and CEFs in the projects improves the availability of maintenance, allows for training of local users, increases the participation of women in technical tasks and, in the end, facilitates the continuity of the project by generating a socially sustainable model.

The business model also has an effect on the social sustainability of the project. From the analysis of the three case studies, EaaS seems to offer better results in improving affordability, which is one of the main challenges in universal access to energy [43]. Besides, EaaS guarantees maintenance and replacement of faulty systems which, in turn, contributes to continued use and (again) to universal access because repairs do not entail additional cost for end users [77].

Funding and subsidization are also key for social sustainability. Both are heavily dependent on the agents involved in the project (states, regulators, and policymakers) and the resulting business model $[79,80]$. For example, only after the negotiations of acciona.org in Peru it was possible to create a regulated EaaS tariff for photovoltaic systems, which in turn made it possible to subsidize the fee and improve affordability of the systems.

\subsection{Environmental Sustainability}

In all three cases the results were similar, a result consistent with the use of the same technological model in the three projects (standalone systems using non-conventional or renewable sources). The positive results confirm previous literature, which identifies this kind of systems as the most adequate choice in rural electrification projects because they can reach remote and disperse communities, have high reliability and provide a more stable access to energy that does not depend on conventional grids nor requires complex infrastructure $[55,81,82]$.

However, the use of systems that have a limited service life (mainly because of the batteries) requires the establishment of protocols to facilitate recycling of the different elements of the SHS, which otherwise would generate toxic waste and damage to the ecosystems [43]. Current trends in rural electrification assess whether it is possible to use fewer batteries to reduce the waste generated by SHS [82] by using independent microgrids that rely on hybrid sources (e.g., solar and diesel) and require much lower battery capacity [69]. For instance, the acciona.org foundation is currently piloting a project in Copal Urco (Peru) to validate the sustainability of the technological model with hybrid sources (using diesel only as a backup source of energy generation).

\subsection{Economic Sustainability}

Economic sustainability is affected by the three main components of the model, as every aspect had a direct impact on the total costs and profitability of the project. First, the use of standalone systems has lower initial and infrastructure deployment costs, which favors economic sustainability [82]. Second, multi-agent governance models also have a positive effect on the economic sustainability of the projects; for instance, when the project incorporates the CLCs, maintenance costs are reduced due to the fact of less frequent trips and higher repair rates [79]. Third, projects operated as EaaS achieve a balance between revenue and costs that facilitates economic sustainability [81], even though profitability is only possible when a regulated tariff and subsidy are in place. This seems to suggest that fee-for-service models (both for system acquisition and maintenance) offer better results regarding economic sustainability. 


\section{Conclusions}

The first part of this study showed a great variety of possible configurations of the management model in rural electrification projects. From a review of the literature, we elaborated a model that showed the different elements of the management model with three main components: governance, technological and business models. The governance model included all aspects relative to the actors involved in the project: owners/promoters or operators and their relationship with other agents, such as financers, regulators, academic institutions, and the communities and users that gain access to energy. The technological model considers choices in the technology based on the location of the communities, their dispersion, proximity to an existing grid, and available sources of energy generation. The business model includes how the systems are acquired and owned, maintenance costs, and the type of contract for service provision.

Our review highlights the concerns of rural electrification project promoters about achieving sustainability and affordability of the service to provide effective universal access while considering the diversity of each context that requires flexible and adaptable solutions. It is very complex to make decisions about the management model that improve the three dimensions of sustainability (social, environmental, and economic) because, most often, economic sustainability (namely, the profitability of the project) becomes the most relevant variable. It is not rare to observe decisions that improve the profitability but at the expense of affordability for end users.

Our analysis of the configurations of the management model of rural electrification projects identified 16 elements and their impact on the dimensions of sustainability. From the analysis, we observed that the environmental sustainability was mostly dependent on the technological model, but the business model had the higher impact on the social and economic sustainability of the project. The analysis of the three case studies under the lens of the management model and its impact on the sustainability of the project facilitated the identification of the strengths, weaknesses and areas of improvement of each project.

The main finding of the study is the key role of the business model and the collaboration between the agents involved in the sustainability of the projects. The choice of the business model is critical, and the analysis showed that fee-for-service models seem more adequate to ensure sustainability of the project. Socially, it allows for affordability of the systems to users in extreme poverty, by combining the fees with subsidies. Economically, in combination with an adequate regulatory framework and subsidization, it facilitates profitability and reduces operation and maintenance costs notably.

Collaboration between agents is essential to achieve sustainability. The analysis of the case studies suggests that variety of roles is important and that the communities and end users must have an active role in the project. In this sense, 5P and involvement of the communities in operational tasks seem to highly favor social sustainability.

The study is not exempt from limitations. Most notably, the three case studies had very similar configurations of the governance and technological models. While this choice allowed us to better understand the effect of the different configurations of the business model on the sustainability of rural electrification projects, a wider selection of case studies with different configurations of the governance and technological model are necessary to better understand the impact of each element of the management model on the different dimensions of sustainability.

Author Contributions: Conceptualization, L.D.-R.-C., S.I.-P. and Á.H.-G.; Methodology, L.D.-R.-C. and E.A.-N.; Validation, L.D.-R.-C., E.A.-N. and S.I.-P.; Formal analysis, L.D.-R.-C. and Á.H.-G.; Investigation, L.D.-R.-C., E.A.-N. and Á.H.-G.; Resources, L.D.-R.-C. and S.I.-P.; writing-original draft preparation, L.D.-R.-C. and Á.H.-G.; writing-review and editing, E.A.-N. and S.I.-P.; Visualization, L.D.-R.-C.; Supervision, S.I.-P.; Project administration, S.I.-P. All authors have read and agreed to the published version of the manuscript.

Funding: This research received no external funding.

Institutional Review Board Statement: Not applicable. 
Informed Consent Statement: Not applicable.

Data Availability Statement: Not applicable.

Acknowledgments: The authors would like to thank the acciona.org foundation for their help and support in the elaboration of this study.

Conflicts of Interest: The authors declare no conflict of interest.

\section{References}

1. World Bank. Access to Energy is at the Heart of Development. 2018. Available online: https://www.worldbank.org/en/news/ feature/2018/04/18/access-energy-sustainable-development-goal-7 (accessed on 15 October 2021).

2. Valentine, S.V. Emerging symbiosis: Renewable energy and energy security. Renew. Sustain. Energy Rev. 2011, 15, 4572-4578. [CrossRef]

3. United Nations. Transforming Our World: The 2030 Agenda for Sustainable Development. 2015. Available online: https: / / undocs.org/A/RES/70/1 (accessed on 29 October 2021).

4. United Nations. Report of the Secretary-General on SDG Progress 2019: Special Edition; United Nations Publications: New York, NY, USA, 2019; pp. 1-64. Available online: https://sustainabledevelopment.un.org/content/documents/24978Report_of_the_SG_ on_SDG_Progress_2019.pdf (accessed on 15 November 2021).

5. C. BP, “Foro de BP de Energía y Sostenibilidad,” Interempresas. 2019. Available online: https://www.bp.com/es_es/spain/ home/noticias/notas-de-prensa/foro-de-energia-y-sostenibilidad-bp---icai.html (accessed on 1 November 2021).

6. Franco, I.B.; Power, C.; Whereat, J. SDG 7 Affordable and clean energy. In Actioning the Global Goals for Local Impact: Towards Sustainability Science, Policy, Education and Practice; Franco, I.B., Chatterji, T., Derbyshire, E., Tracey, J., Eds.; Springer: Singapore, 2020; pp. 105-116.

7. Chu, S.; Majumdar, A. Opportunities and challenges for a sustainable energy future. Nature 2012, 488, 294-303. [CrossRef]

8. World Bank. The Welfare Impact of Rural Electrification: A Reassessment of the Costs and Benefits. 2008. Available online: http:/ / lnweb90.worldbank.org/oed/oeddoclib.nsf/DocUNIDViewForJavaSearch/EDCCC33082FF8BEE852574EF006E5 539/\$file/rural_elec_full_eval.pdf (accessed on 21 October 2021).

9. Sovacool, B.K. The political economy of energy poverty: A review of key challenges. Energy Sustain. Dev. 2012, 16, 272-282. [CrossRef]

10. Del-Río-Carazo, L.; Iglesias-Pradas, S.; Acquila-Natale, E.; Martín-Fernández, J.G. Appropriate Technology for Access to Universal Basic Services: A Case Study on Basic Electricity Service Provision to Remote Communities in the Napo River Basin. Sustainability 2022, 14, 132. [CrossRef]

11. Chaurey, A.; Krithika, P.R.; Palit, D.; Rakesh, S.; Sovacool, B.K. New partnerships and business models for facilitating energy access. Energy Policy 2012, 47 (Suppl. 1), 48-55. [CrossRef]

12. Schillebeeckx, S.J.D.; Parikh, P.; Bansal, R.; George, G. An integrated framework for rural electrification: Adopting a user-centric approach to business model development. Energy Policy 2012, 48, 687-697. [CrossRef]

13. Lillo, P.; Ferrer-Martí, L.; Juanpera, M. Strengthening the sustainability of rural electrification projects: Renewable energy, management models and energy transitions in Peru, Ecuador and Bolivia. Energy Res. Soc. Sci. 2021, 80, 102222. [CrossRef]

14. Eras-Almeida, A.A.; Fernández, M.; Eisman, J.; Martín, J.G.; Caamaño, E.; Egido-Aguilera, M.A. Lessons learned from rural electrification experiences with third generation solar home systems in Latin America: Case studies in Peru, Mexico, and Bolivia. Sustainability 2019, 11, 7139. [CrossRef]

15. World Bank. Perú Rural Electrification; ESMAP: Washington, DC, USA, 2001; Available online: https:/ / openknowledge.worldbank. org/handle/10986/20300?locale-attribute=en (accessed on 3 October 2021).

16. Crousillat, E.; Hamilton, R.; Antmann, P. Addressing the Electricity Access Gap. Background Paper for the World Bank Group Energy Strategy. 2010. Available online: https:/ / openknowledge.worldbank.org/bitstream/handle/10986/12530/690620ESW0 whit0s0Gap0Final0Version.pdf?sequence $=1$ \&isAllowed=y (accessed on 4 November 2021).

17. Greeley, M. Rural energy technology assessment: A Sri Lankan case study. World Dev. 1986, 14, 1411-1421. [CrossRef]

18. Diouf, B.; Pode, R.; Osei, R. Initiative for 100\% rural electrification in developing countries: Case study of Senegal. Energy Policy 2013, 59, 926-930. [CrossRef]

19. Herbert, C.; Phimister, E. Private sector-owned mini-grids and rural electrification: A case study of wind-power in Kenya's tea industry. Energy Policy 2019, 132, 1288-1297. [CrossRef]

20. Ilskog, E.; Kjellström, B. And then they lived sustainably ever after? Assessment of rural electrification cases by means of indicators. Energy Policy 2008, 36, 2008. [CrossRef]

21. Horiuchi, K. Diverse interpretations enabling the continuity of community renewable energy projects: A case study of a woody biomass project in rural area of Japan. Local Econ. 2018, 33, 2018. [CrossRef]

22. Yadoo, A.; Cruickshank, H. The value of cooperatives in rural electrification. Energy Policy 2010, 38, 2941-2947. [CrossRef]

23. Lillo, P.; Ferrer-Martí, L.; Boni, A.; Fernández-Baldor, Á. Assessing management models for off-grid renewable energy electrification projects using the Human Development approach: Case study in Peru. Energy Sustain. Dev. 2015, 25, 17-26. [CrossRef] 
24. Madriz-Vargas, R.; Anna, B.; Muriel, W.; Alvarado, R.Y. Energy with development: 50 years' experience of community-driven rural electrification and future challenges for COOPEGUANACASTE in Costa Rica. In Proceedings of the Asia-Pacific Solar Research Conference, Canberra, Australia, 29 November-1 December 2016; pp. 1-12.

25. Judith, I.S.; Tarquino, M.; Cooper, D. Humanitarian Energy: Energy for Micro-Enterprises in Displacement Settings. 2020. Available online: https://endev.info/wp-content/uploads/2021/04/EnDev_Learning_and_Innovation_Humanitarian_Energy. pdf (accessed on 1 December 2021).

26. Gómez-Hernández, F.; Domenech, B.; Moreira, J.; Farrera, N.; López-González, A.; Ferrer-Martí, L. Comparative evaluation of rural electrification project plans: A case study in Mexico. Energy Policy 2019, 129, 23-33. [CrossRef]

27. Sovacool, B.K. Expanding renewable energy access with pro-poor public private partnerships in the developing world. Energy Strateg. Rev. 2013, 1, 181-192. [CrossRef]

28. IEA. Defining Energy Access: 2020 Methodology. 2020. Available online: https://www.iea.org/articles/defining-energy-access2020-methodology (accessed on 20 October 2021).

29. Nagarjun, Y. Effectiveness of On-grid and Off-grid rural electrification approaches in India. In Proceedings of the 2015 International Conference on Sustainable Energy Engineering and Application (ICSEEA), Bandung, Indonesia, 5-7 October 2015. [CrossRef]

30. Peters, J.; Sievert, M. Impacts of rural electrification revisited: The African context. Rev. Econ. Dev. 2016, 23, 77-98. [CrossRef]

31. Barnes, D.F. Effective solutions for rural electrification in developing countries: Lessons from successful programs. Curr. Opin. Environ. Sustain. 2011, 3, 260-264. [CrossRef]

32. Kanase-Patil, A.B.; Saini, R.P.; Sharma, M.P. Integrated renewable energy systems for off grid rural electrification of remote area. Renew. Energy 2010, 35, 1342-1349. [CrossRef]

33. Hatziargyriou, N.; Asano, H.; Iravani, R.; Marnay, C. An Overview of Ongoing Research, Development, and Demonstration. IEEE Power Energy Mag. 2007, 78. Available online: https:/ / studylib.net/doc/18129150/microgrids--an-overview-of-ongoingresearch--development-and (accessed on 29 September 2021). [CrossRef]

34. Gullberg, M.; Ilskog, E.; Katyega, M.; Kjellström, B. Village electrification technologies—An evaluation of photovoltaic cells and compact fluorescent lamps and their applicability in rural villages based on a Tanzanian case study. Energy Policy 2005, 33, 1287-1298. [CrossRef]

35. Kamalapur, G.D.; Udaykumar, R.Y. Electrification in rural areas of India and consideration of SHS. In Proceedings of the 2010 5th International Conference on Industrial and Information Systems, Mangalore, India, 29 July-1 August 2010. [CrossRef]

36. Mandelli, S.; Barbieri, J.; Mereu, R.; Colombo, E. Off-grid systems for rural electrification in developing countries: Definitions, classification and a comprehensive literature review. Renew. Sustain. Energy Rev. 2016, 58, 1621-1646. [CrossRef]

37. Chakrabarti, S.; Chakrabarti, S. Rural electrification programme with solar energy in remote region-A case study in an island. Energy Policy 2002, 30, 33-42. [CrossRef]

38. Bernardo, F.P.; Kilayko, G.U. Promoting rural energy technology: The case of gasifiers in the Philippines. World Dev. 1990, 18, 565-574. [CrossRef]

39. Hiremath, R.B.; Kumar, B.; Balachandra, P.; Ravindranath, N.H. Bottom-up approach for decentralised energy planning: Case study of Tumkur district in India. Energy Policy 2010, 38, 862-874. [CrossRef]

40. Wolde-Ghiorgis, W. Renewable energy for rural development in Ethiopia: The case for new energy policies and institutional reform. Energy Policy 2002, 30, 1095-1105. [CrossRef]

41. Akorede, M.F.; Hizam, H.; Pouresmaeil, E. Distributed energy resources and benefits to the environment. Renew. Sustain. Energy Rev. 2010, 14, 724-734. [CrossRef]

42. Lahimer, A.A.; Alghoul, M.A.; Yousif, F.; Razykov, T.M.; Amin, N.; Sopian, K. Research and development aspects on decentralized electrification options for rural household. Renew. Sustain. Energy Rev. 2013, 24, 314-324. [CrossRef]

43. Balachandra, P. Modern energy access to all in rural India: An integrated implementation strategy. Energy Policy 2011, 39, 7803-7814. [CrossRef]

44. Morris, E.; Winiecki, J.; Chowdhary, S.; Cortiglia, K. Using Microfinance to Expand Access to Energy Services: Summary of Findings. 2007. Available online: http://pdf.usaid.gov/pdf_docs/Pnadm641.pdf (accessed on 15 November 2021).

45. Ottinger, R.L.; Bowie, J. Innovative financing for renewable energy. Energy Gov. Sustain. 2016, 32, 125-148. [CrossRef]

46. Painuly, J.P.; Wohlgemuth, N. Renewable energy financing-What can we learn from experience in developing countries? Energy Stud. Rev. 2008, 14, 154-170. [CrossRef]

47. Williams, N.J.; Jaramillo, P.; Taneja, J.; Ustun, T.S. Enabling private sector investment in microgrid-based rural electrification in developing countries: A review. Renew. Sustain. Energy Rev. 2015, 52, 1268-1281. [CrossRef]

48. Ezor, Z. Power to the People: Rural Electrification in Uganda. ISP Collection. 2009, p. 35. Available online: http:// digitalcollections.sit.edu/cgi/viewcontent.cgi?article=1675\&context=isp_collection (accessed on 10 November 2021).

49. Palit, D. Solar energy programs for rural electrification: Experiences and lessons from South Asia. Energy Sustain. Dev. 2013, 17, 270-279. [CrossRef]

50. Lozano, L.; Taboada, E.B. Elucidating the challenges and risks of rural island electrification from the end-users' perspective: A case study in the Philippines. Energy Policy 2020, 150, 112143. [CrossRef]

51. Bhattacharjya, B.R.; Kakoty, S.K.; Singha, S. A feedback mechanism for appropriate technology development and dissemination: Case study approach. Technol. Soc. 2019, 57, 104-114. [CrossRef] 
52. AI-Ali, S. Developing countries and technology transfer. Int. J. Technol. Manag. 1995, 10, 704-713.

53. Wensing, A.J.; Wensing, E.J.; Virgo, M. Towards a core curriculum for civic engagement on appropriate technology: Characterizing, optimizing and mobilizing youth community service learning. Afr. J. Sci. Technol. Innov. Dev. 2018, 10, 867-877. [CrossRef]

54. Gómez, M.F.; Silveira, S. Delivering off-grid electricity systems in the Brazilian Amazon. Energy Sustain. Dev. 2012, 16, 155-167. [CrossRef]

55. WCED. Our Common Future: Report of the World Commission on Environment and Development. Med. War 1987, 5, 17-25. [CrossRef]

56. Purvis, B.; Mao, Y.; Robinson, D. Three pillars of sustainability: In search of conceptual origins. Sustain. Sci. 2019, 14, 681-695. [CrossRef]

57. Gilbert, R.; Stevenson, D.; Girardet, H.; Stren, R. Making Cities Work: Role of Local Authorities in the Urban Environment; Routledge: London, UK, 1996.

58. Black, A.W. The Quest for Sustainable, Healthy Communities. Aust. J. Environ. Educ. 2004, 20, 33-44. [CrossRef]

59. Moldan, B.; Janoušková, S.; Hák, T. How to understand and measure environmental sustainability: Indicators and targets. Ecol. Indic. 2012, 17, 4-13. [CrossRef]

60. Giddings, B.; Hopwood, B.; O’Brien, G. Environment, Economy and Society: Fitting Them Together into Sustainable Development Sustain. Dev. 2002, 10, 187-196. [CrossRef]

61. Martens, M.L.; Carvalho, M.M. Key factors of sustainability in project management context: A survey exploring the project managers' perspective. Int. J. Proj. Manag. 2017, 35, 1084-1102. [CrossRef]

62. Singh, R.K.; Murty, H.R.; Gupta, S.K.; Dikshit, A.K. An overview of sustainability assessment methodologies. Ecol. Indic. 2009, 9, 189-212. [CrossRef]

63. López-González, A.; Domenech, B.; Ferrer-Martí, L. Formative evaluation of sustainability in rural electrification programs from a management perspective: A case study from Venezuela. Renew. Sustain. Energy Rev. 2017, 95, 95-109. [CrossRef]

64. Mainali, B.; Silveira, S. Using a sustainability index to assess energy technologies for rural electrification. Renew. Sustain. Energy Rev. 2015, 41, 1351-1365. [CrossRef]

65. Boliko, C.M.; Ialnazov, D.S. An assessment of rural electrification projects in Kenya using a sustainability framework. Energy Policy 2019, 133, 110928. [CrossRef]

66. Brent, A.C.; Rogers, D.E. Renewable rural electrification: Sustainability assessment of mini-hybrid off-grid technological systems in the African context. Renew. Energy 2010, 35, 257-265. [CrossRef]

67. Bueno-Lopez, M.; Rodriguez-Sanchez, P.; Molinas, M. Sustainable model for rural electrification projects in Non-Interconnected Areas in Colombia. In Proceedings of the 2019 IEEE Global Humanitarian Technology Conference (GHTC), Seattle, WA, USA, 17-20 October 2019. [CrossRef]

68. Ilskog, E. Rural Electrification Sustainability Indicators: Manual for Field Workers; KTH University Press: Stockholm, Sweden, 2008, Available online: http:/ / www.diva-portal.org/smash/record.jsf?pid=diva2:25019 (accessed on 16 November 2021).

69. López-González, A.; Domenech, B.; Ferrer-Martí, L. Sustainability evaluation of rural electrification in Cuba: From fossil fuels to modular photovoltaic systems: Case studies from sancti spiritus province. Energies 2021, 14, 2480. [CrossRef]

70. Jami, A.A.; Walsh, P.R. From consultation to collaboration: A participatory framework for positive community engagement with wind energy projects in Ontario, Canada. Energy Res. Soc. Sci. 2017, 27, 14-24. [CrossRef]

71. INEI. Status of the Peruvian Population. 2020. Available online: https://www.inei.gob.pe/estadisticas/indice-tematico/ population/ (accessed on 20 June 2021).

72. Falcón-Roque, E.J.; Martín, F.M.; Castaño, C.P.; Domínguez-Dafauce, L.C.; Flores, F.J.B. Energy planning model with renewable energy using optimization multicriteria techniques for isolated rural communities: Cajamarca province, Peru. J. Renew. Sustain. Energy 2017, 9, 065903. [CrossRef]

73. Narayan, N.; Chamseddine, A.; Vega-Garita, V.; Qin, Z.; Popovic-Gerber, J.; Bauer, P.; Zeman, M. Exploring the boundaries of Solar Home Systems (SHS) for off-grid electrification: Optimal SHS sizing for the multi-tier framework for household electricity access. Appl. Energy 2018, 240, 907-917. [CrossRef]

74. Fernandez-Fuentes, M.H.; Eras-Almeida, A.A.; Egido-Aguilera, M.A. Characterization of technological innovations in photovoltaic rural electrification, based on the experiences of Bolivia, Peru, and Argentina: Third generation solar home systems. Sustainability 2021, 13, 3032. [CrossRef]

75. Instituto Nacional de Estadística y Geografía INEGI. Acceso a Electricidad México. 2010. Available online: https://www.inegi. org.mx/programas/encevi/2018/ (accessed on 20 October 2021).

76. Podder, S.; Khan, M.Z.R. Comparison of lead acid and Li-ion battery in solar home system of Bangladesh. In Proceedings of the 2016 5th International Conference of Informatics, Electronics and Vision, ICIEV, Dhaka, Bangladesh, 13-14 May 2016; pp. 434-438. [CrossRef]

77. Yadav, P.; Heynen, A.P.; Palit, D. Pay-As-You-Go financing: A model for viable and widespread deployment of solar home systems in rural India. Energy Sustain. Dev. 2019, 48, 139-153. [CrossRef]

78. IEA. Financing Mechanisms for Solar Home Systems in Developing Countries. The Role of Financing in The Dissemination Process. 2003. Available online: https:/ /iea-pvps.org/wp-content/uploads/2020/01/rep9_01.pdf (accessed on 28 November 2021).

79. Lemaire, X. Fee-for-service companies for rural electrification with photovoltaic systems: The case of Zambia. Energy Sustain. Dev. 2009, 13, 18-23. [CrossRef] 
80. Baurzhan, S.; Jenkins, G.P. Off-grid solar PV: Is it an affordable or appropriate solution for rural electrification in Sub-Saharan African countries? Renew. Sustain. Energy Rev. 2016, 60, 1405-1418. [CrossRef]

81. Liu, Y.; Yu, S.; Zhu, Y.; Wang, D.; Liu, J. Modeling, planning, application and management of energy systems for isolated areas: A review. Renew. Sustain. Energy Rev. 2018, 82, 460-470. [CrossRef]

82. Mamaghani, A.H.; Escandon, S.A.A.; Najafi, B.; Shirazi, A.; Rinaldi, F. Techno-economic feasibility of photovoltaic, wind, diesel and hybrid electrification systems for off-grid rural electrification in Colombia. Renew. Energy 2016, 97, 293-305. [CrossRef] 